\title{
Research on the construction of teachers in Higher Vocational Colleges -- A case study of 2004-2013 in Shaanxi Province
}

\author{
Zhang Yingjie \\ Liaoning Urban Construction Technical College, Shenyang, Liaoning, \\ 110122
}

\begin{abstract}
The development of teachers is the key to promote the development of education, is the core element of occupation education development, is one of the key factors ensuring the quality of education and teaching, and also the main contents of the connotation construction of occupation colleges. This paper based on the data of 2004-2013, the current situation of the development of Higher Vocational College Teachers in Shaanxi province were investigated and analyzed, summarized the main problems teachers in the development, and put forward the further development and improvement suggestions, so as to provide basis for the construction of teachers in Higher Vocational Colleges of Shaanxi province.

Keywords: Shaanxi province; higher vocational colleges; teachers' construction; investigation and analysis
\end{abstract}

\section{Introduction}

General secretary Xi Jinping proposed the development of "Belt and Road Initiative" on 2013 ("Silk Road Economic Belt" in twenty-first Century and "maritime Silk Road") strategy. This strategy will fully mobilize the east coast of China and Shaanxi, Gansu and other western regions to promote the advantages of countries along in the energy, Finance and agriculture etc. in terms of cooperation, and ultimately enhance the national economic level. The world renowned consulting firm McKinsey through survey: the primary factor $88 \%$ 
executives that "overseas cooperation's success lies in talents". Therefore, the development strategy of "The Belt and Road" not only provides new opportunities for the development of talents, put forward new requirements also on the quality and ability of talents in Higher Vocational Colleges as the cradle. Areas of talent training, will also face strengthen connotation construction, improve the training of new challenges. The quality of the teachers in Higher Vocational Colleges One of the core contents of connotation construction of colleges and universities. However, the quantity and quality of teachers in higher vocational colleges are difficult to meet the needs of the rapid development of higher occupation education, especially in underdeveloped areas, the development of higher vocational education is slow. In order to cater to the development strategy of "The Belt and Road", as the technical skills of personnel Shaanxi and other central and western regions to train more high-quality, it is imperative to strengthen the construction of teachers. This paper takes Shaanxi Province as a case, through the questionnaire and Literature Education Statistical Yearbook, Shaanxi province existing vocational teachers, to take measures to promote Shaanxi Province has a positive role in the development of higher vocational teachers.

The questionnaire sample obtained by random sampling method, to select the ordinary colleges and universities of Shaanxi Province, the provincial Demonstration Vocational Colleges and the national demonstration vocational colleges 2, in each college and a random sample of three a total of 30 professional teachers (each professional selected 10 people) survey at the same time; from private enterprises, state-owned enterprises and foreign enterprises of the 2 companies, each company selected 20 samples. The survey issued a total of 300 questionnaires, including 180 teacher questionnaires, 120 questionnaires of enterprises. 300 questionnaires, 290 valid questionnaires, the questionnaire recovery rate and effective rate were $100 \%$ and $96 \%$.

\section{The present situation of teachers in Higher Vocational Colleges in Shaanxi}

From the total number of staff to see (see chart 1 and chart 2), 2004 to 2012 years of little change, in 2012 the total number of staff 20353 people, more than 20597 people in 2004, a decrease of 244 people. The full-time teachers showing a growth trend, from 9410 in 2004, increased to 12688 in 2012, an increase of 3278 $34.8 \%$, an increase of full-time teachers accounted for the proportion of the total number of staff from $45.69 \%$ in 2004 , increased to $62.34 \%$, an increase of 16.65 percentage points. The total number of staff in the case of little change, the number of full-time teachers and the proportion increased significantly, indicating a structure to optimize the teaching staff. 


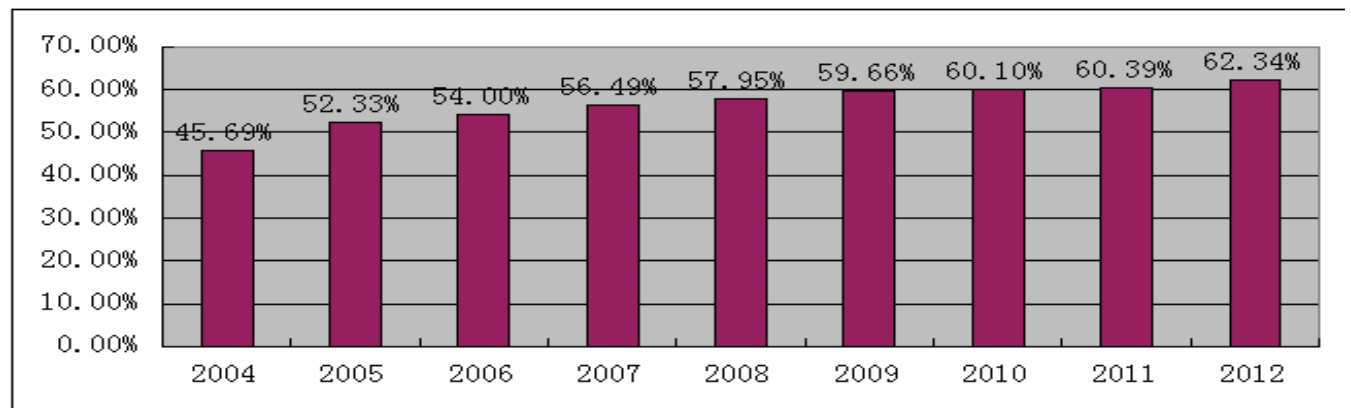

Figure 1 the proportion of secondary vocational teachers in Higher Vocational Colleges

From the perspective of students (see chart 3), from 2005 to 2010 has been in a growth trend, the decline in 2011, 2012 began to increase, reached 236333. Compared with 2004, in 2012 the independent set of vocational college students increased by 98003 people, which is mainly due to the higher education enrollment caused by year.

Although in recent years full-time teachers accounted for the total number of staff increased rate, but with the expansion of the scale of higher occupation education, the number of full-time teachers still can not meet the needs of the development of higher occupation education. Teachers and students from the ratio (see chart 4), since 2004 has been in a fluctuating growth, 2004 years to reach the teacher-student ratio is 1:152012 1:19, the proportion is still higher than the national vocational college teachers and students than the 1:16 level.

teachers' Professional Title Structure

From the title structure of full-time teachers to see (see chart 5 and table 1), 2004 to 2012 years of full-time teachers without title proportion fluctuated between $6.26 \%$ to $8.66 \%$, little change in.2012 years without professional teachers accounted for $6.26 \%$.

Table 1 the higher occupation colleges at all levels of professional teachers accounted for the proportion of the total number of full-time teachers (\%)

\begin{tabular}{|l|l|l|l|l|l|l|l|l|l|}
\hline & 2004 & 2005 & 2006 & 2007 & 2008 & 2009 & 2010 & 2011 & 2012 \\
\hline None & 7.16 & 8.66 & 8.31 & 7.1 & 7.26 & 8.17 & 7.20 & 6.78 & 6.26 \\
\hline Primary & 28.66 & 25.33 & 25.77 & 27.84 & 27.96 & 27.78 & 27.57 & 26.94 & 27.88 \\
\hline Middle & 35.5 & 38.1 & 37.23 & 37.2 & 37.59 & 37.86 & 38.87 & 39.94 & 40.15 \\
\hline Senior & 23.04 & 24.45 & 24.61 & 23.92 & 23.49 & 22.43 & 22.21 & 22.04 & 21.82 \\
\hline High & 5.63 & 3.46 & 4.08 & 3.95 & 3.70 & 3.76 & 4.16 & 4.3 & 3.86 \\
\hline
\end{tabular}

In 2004, full-time teachers of junior titles accounted for $28.66 \%$ of the total number of full-time teachers, 20052006 years down to a little more than $25 \%$ since 2007 , basically stable at around $27 \%$, little change;

The intermediate title of full-time teachers in the proportion of fluctuated upward trend, rising from $35.5 \%$ in 2004 to $40.15 \%$ in 2012 , an increase of 4.65 percentage points;

Vice senior Title Teachers proportion showed a downward trend, fell from $23.04 \%$ in 2004 to $21.82 \%$ in 2012 , down 1.22 percentage points; 
In 2004, full-time teachers are high titles accounted for $5.63 \%$, after has been around 4\% fluctuation, $20123.86 \%$.

From the change trend from 2004 to 2012, the intermediate title of full-time teachers the proportion of the biggest change, an increase of 4.65 percentage points, other titles of full-time teachers in the proportion of little change.

Overall, from 2012 the title structure of full-time teachers, intermediate titles accounted for the total number of full-time teachers in $40.15 \%$, is the subject of full-time teachers.

From the teacher's training level (see chart 6), the training is the main body, the proportion reached $44.23 \%$, followed by municipal, provincial and national level, this is mainly because of the above training needs after the selection, usually the backbone teachers to participate.

Trained teachers from the content (see chart 7), curriculum development, teaching methods and occupation education theory is the main content of vocational training teachers, the proportion was $55.47 \%$, the main reason is that the $48.18 \%$ and $45.26 \%$.: one is the curriculum and teaching is the core content of the reform of higher occupation education in recent years, is the key to improve the quality of education; two is to learn the concept of vocational education theory can contribute to the change of teachers, improve teaching and curriculum reform. With the relative low proportion of teachers to participate in the enterprise practice and education scientific research training, only $24.82 \%$ and $10.95 \%$. on the one hand, and the enterprise acceptance of teachers' practice intention. On Teachers' ability of education and scientific research. On the other hand the occupation colleges do not pay enough attention, which is caused by the current teachers in Higher Vocational College "Double Teachers" quality and scientific research ability of ordinary low.

Survey data show (see chart 8), there are $34.62 \%$ higher vocational teachers with enterprise work experience. This is mainly because of Higher Vocational College Teachers' social status and treatment is relatively good, many higher vocational colleges have developed enterprises actively introduce excellent technical personnel into the school to teach the support policy, can attract the excellent talents of some enterprises, but overall the enterprise has experienced teachers, the proportion is still low.

Teachers' occupation practice admission enterprises, almost is the basic content of cooperation between all occupation colleges. The survey data show (see chart 9), provides for the occupation colleges in support of enterprise projects, acceptance of teachers' practice and the proportion was only $29.20 \%$.

The investigation shows that teachers in higher vocational colleges is basically completed by students with internship in the occupation practice of enterprises, that is to say about the production practice and the production process of enterprises in the course of practice with the students, but this kind of understanding is very limited. Only individual cooperation deeply into the school, teachers will be a practice time in the production process of enterprises, have the opportunity to participate in the enterprise, understand the production process of the enterprise. 


\section{The problems in the development of teachers in Higher Vocational Colleges in Shaanxi}

Through the present situation of Higher Vocational Colleges in Shaanxi province. The analysis shows that the teachers in Vocational Colleges in Shaanxi Province, there are still some problems in the process of development, mainly as follows:

With the expansion of the scale of higher occupation education in Shaanxi Province, the number of teachers in Higher Vocational Colleges to meet the needs of the development of higher occupation education. The survey data show that: Although the number of teachers, especially the number of full-time teachers increased significantly, but still unable to meet the needs of higher occupation education career development in 2012, set up independently in Shaanxi province than the teachers and students in Higher Vocational Colleges up to $1: 19$, far beyond the provisions of the state $1: 16$ level. This shows that the number of teachers in higher vocational colleges is seriously insufficient, will become the key factors affecting the quality of higher occupation education.

(two) the teachers generally lack the background of industrial enterprises, lack of practical experience

At present, constitute the main occupation college teachers in China are college graduates, mainly from the ordinary higher school graduates employed directly, a very limited number of teachers from the introduction of enterprises in the industry survey data also support the view that higher vocational colleges of Shaanxi province with the enterprise work experience accounted for only $34.62 \%$. this shows that the teachers in Shaanxi province team in higher vocational colleges, there are still nearly $2 / 3$ of the teachers are lack of industry background. At the same time, China's higher occupation education innovation and development "action plan (2015-2018)" proposed "professional teachers in Higher Vocational Colleges every five years of business practice time a total of not less than 6 months. Although at the national level with the policy guidance, but is currently in the process of the development of teachers in higher vocational colleges, the implementation of this policy is not optimistic, most teachers lack in enterprise practice, survey data also support the view that in Shaanxi, the proportion of enterprises accept the teachers' practice is only $29.20 \%$. which indicates that higher vocational teachers lack enterprise practical experience, the construction of" double type teachers still need to be further strengthened. (three) the level and pertinence of teacher training need to be improved

The quality of teachers directly affects the quality of vocational education, so teachers to participate in training to improve the quality of teachers, is of great significance to promote the quality of education. The survey data show: teachers of Higher Vocational Colleges in Shaanxi province participated in the training are mostly school-based training, training programs, and above the proportion is low. This is mainly because the municipal level and above need to get through the selection of training project training qualifications, usually in Higher Vocational Colleges Teachers to participate in training, but the high level also determines the depth and breadth of training content, therefore, in order to improve the overall quality of teachers, teachers' participation in high-level 
training programs is still need to be improved.

At the same time, in the training content, training contents of most teachers are involved in curriculum and teaching, this is mainly because the curriculum and teaching is the core of all education, enrich the curriculum of higher vocational teachers and teaching knowledge, has a positive role to improve the teaching quality of higher vocational teachers. At the same time, the so-called "teaching, teaching reform is the first" teaching and research work, is one of the tasks of teachers in higher vocational colleges, improve the ability of scientific research of teachers to improve the teaching quality of higher vocational colleges also has an indelible role. However, we found that teachers in Higher Vocational Colleges of Shaanxi province to participate in the teaching and research aspects of the training ratio is only $10.95 \%$, which indicates that higher vocational colleges attach great importance to the development of teachers' scientific research ability teaching is not enough, resulting in higher vocational colleges teachers scientific research ability is generally weak, this further shows that teachers participated in the training project Targeted is not strong, to be further improved

Three, the Countermeasures for the development of teachers in Higher Vocational Colleges in Shaanxi

The main reason is lack of teachers in higher vocational colleges is the industry background of China's Higher Vocational Colleges from the school to the school recruitment system determines the majority of teachers in higher vocational colleges directly imported from college graduates. However, because of the characteristics of occupation education determines the vocational college teachers must have a certain occupation practice experience, understand the enterprise post production and business process. Therefore, higher vocational colleges should be based on the higher vocational education teachers professional standards and requirements, the establishment of vocational teachers qualification system, develop vocational college teachers' work reflects the characteristics of qualifications, work experience and increase enterprise occupation ability, we suggested that the basic requirements of "double quality" into the qualification of teachers in higher vocational colleges that strict entrance of teachers.

(two) to strengthen the construction of double qualified teachers and improve the quality of Teachers

The "double" teachers is the key of higher occupation education connotation construction, occupation education occupation and practical decision of teachers in higher vocational colleges must have a "double quality". In order to adapt to the development of higher occupation education in Shaanxi Province, Shaanxi Province Higher Vocational Colleges to strengthen the construction of the "double" teachers on the one hand, to increase the teachers' efforts to introduce, expanding the number of full-time teachers, the number of teachers in Higher Vocational Colleges to meet the needs of the development of higher vocational education, optimize the teacher-student ratio; on the other hand to introduce enterprise outstanding technical personnel to school as part-time teachers, improve the proportion of part-time teachers, and sends some teachers to enterprises for occupation practice, improving teachers' practical ability.

(three) to mobilize the enthusiasm of enterprises to promote the practice of 
Higher Vocational Teachers

The sustainable development of occupation education cannot do without the introduction of enterprises, enterprises to participate in the occupation education preferential policies, enhance the enthusiasm of enterprises to participate in the training of teachers in higher vocational colleges, there will be conducive to enterprise cooperation and training of teachers in Higher Vocational Colleges smoothly, mainly from three aspects: one is a hand to guide enterprises to actively participate in the occupation education. Play the dominant position of enterprises in the occupation education in two; in enterprises to participate in the occupation education, enterprises in the form of currency expenditure, such as the formation of students' practice and teachers' practice in the process of equipment occupied consumption, material consumption, payment to the students paid can be included in the production cost, the base pay is not included in the enterprise according to the existing regulations, in the calculation of enterprise income tax deduction; three is the occupation education, for outstanding contributions to the enterprise, depending on the degree of its contribution. Local tax relief, relief ratio can fluctuate between $3 \%-5 \%$

Teachers in Higher Vocational Colleges to practice, to improve their practice ability, specifically from the following two aspects:

One is to establish a vocational teacher's business practice system. At present, most of the teachers are from the occupation college school of graduation to the school, the lack of business experience, do not understand the professional correspondence as the enterprise work and actual work flow. Therefore, we should establish and perfect the enterprise system and the practice of teachers guidance actively call for occupation colleges to encourage teachers to take regular full-time or post training and other forms of participation in the actual project of enterprises, training and practice of the system and program, the establishment of teacher practice enterprise system, improve the policy mechanism of double type teachers team construction. Suggestions in occupation colleges professional titles, increase business experience and practice examination, strengthen the enterprise practice intermediate above title teacher's experience, improve the occupation college teachers to enterprises to participate in the corporate practice consciousness.

The two is to strengthen the occupation education teacher training base construction enterprises as the center. The teachers occupation education training base at present are located at the university or higher occupation colleges. Suggestions for the selection of a number of industry representative enterprises, as a professional teaching practice base class occupation colleges, and the national training base, establish cooperative relations training provincial counterparts teachers of vocational education, make full use of the project resources, play to the advantages of the industry, focused on the use of summer vacation time, or do not hold regular training of double type teachers occupation colleges help backbone, the training of "Double Teachers", familiar with the work, familiar with the project implementation process, for the establishment of a comprehensive enterprise practice teacher system. The innovation of teacher training model to provide a platform and carrier. 
(four) provide targeted training for teachers to improve the overall quality of Teachers.

The teacher is the subject of education, teachers' quality affects the quality of teaching to a great extent. To strengthen the training of teachers in Higher Vocational Colleges and improve the teaching quality.

One is the key to strengthen the cultivation of professional leaders. The professional leaders responsible for the construction and development of professional quality, it can lead to the improvement of the whole team to improve the quality of professional leaders. After the training, you can re training for the professional teachers, led the professional teachers to conduct professional construction, and thus play a multiplier effect.

The two is for teachers to provide targeted training. In the training level, can take the national training, provincial training and school-based training combination, teachers give full play to the national and provincial capital of vocational training base advantage, more than a year to teachers to participate in the national training and cultivating project. The content of the training. According to the different types of teachers should provide targeted training courses for enterprises. For example the practical experience of teachers should focus on strengthening the teaching methods, teaching design and teaching research for lack of occupation training; practice teachers should focus to strengthen the occupation skills, practical ability training. In the training mode, to provide participation for more training, the teachers to improve the ability and quality in the process of participation. For example, hire experts to participate in the training methods were used on curriculum development technology, teaching design, teaching Research and other aspects of training, so that teachers in the process of doing the relevant technology and methods.

The three is to strengthen the construction of teachers' team. Strengthen the communication between teachers, exchanges and cooperation, the formation of a learning team of teachers, so as to improve the overall level of the teachers.

\section{References}

[1] Lin Sheng. Discussion on the Relationship between Resource Protection and Ecological Tourism in Wuyishan Nature Reserve. Ecological economy, 55(12), pp.68-70, 2011

[2] Discussion on Eco - tourism Development of Nature Reserves in China. Human Geography, 8 (5), pp.87- 91, 2013

[3] Development Strategies of Eco - tourism in Nature Reserves of China. Journal of Jiaozuo Teachers College, 12(10), pp. 18- 20, 2012

[4] Sun G N. Study on the development model of ecotourism in nature reserves in China. Resources Science, 9(6), pp.58- 61, 2011

[5] Huang Xiaoling. Preliminary Study on Tourism Product Development of Wuyishan Nature Reserve, Problems of Forestry Economy 8(4), pp.85-87, 2014 